\title{
Phytoprotection
}

\section{Interfertility between Armillaria cepistipes and $A$. sinapina}

\section{J.A. Bérubé, M. Dessureault, S. Berthelay et J.-J. Guillaumin}

Volume 77, numéro 2, 1996

URI : https://id.erudit.org/iderudit/706101ar

DOI : https://doi.org/10.7202/706101ar

Aller au sommaire du numéro

\section{Éditeur(s)}

Société de protection des plantes du Québec (SPPQ)l

\section{ISSN}

0031-9511 (imprimé)

1710-1603 (numérique)

\section{Découvrir la revue}

\section{Citer cet article}

Bérubé, J., Dessureault, M., Berthelay, S. \& Guillaumin, J.-J. (1996). Interfertility between Armillaria cepistipes and A. sinapina. Phytoprotection, 77(2), 67-74. https://doi.org/10.7202/706101ar

\section{Résumé de l'article}

Des études ont rapporté que des lignées européennes d'Armillaria cepistipes étaient interfertiles avec trois lignées américaines d'Armillaria désignées par les termes espèce biologique nord-américaine (NABS) V (A sinapina), NABS X et NABS XI. Une telle interfertilité entre les espèces soulève des doutes au sujet de l'utilisation de binômes latins distincts pour des espèces pouvant se reproduire. Cette interfertilité a été ré-examinée en mettant 24 isolats haploïdes d'A cepistipes européen en présence de 23 isolats 6'A. sinapina d'Amérique du Nord et d'Asie. Les appariements individuels ont été effectués de façon indépendante au moins une fois à l'Université Laval (Canada) et à NNRA Clermont-Ferrand (France). Des 420 appariements interspécifiques effectués à l'Université Laval, deux étaient positifs et sept étaient ambigus, pour un total de $2,1 \%$ de tous les appariements. Des 506 appariements effectués à Clermont-Ferrand, 10 étaient positifs et 24 étaient ambigus pour un total de 6,7 \% des appariements. Les différences dans les résultats de ces appariements peuvent être expliquées par les températures d'incubation, ainsi que par les différents types et concentrations d'extrait de malt utilisés dans chaque laboratoire. Les bas niveaux d'interfertilité trouvés entre $A$ cepistipes et $A$. sinapina peuvent résulter de l'absence de barrières génétiques habituellement présentes entre des espèces sympatriques. Ce bas niveau d'interfertilité reflète des différences entre la morphologie, la répartition et les habitats des deux espèces d'Armillaria, et appuie la conservation de dénominations d'espèces distinctes.
Ce document est protégé par la loi sur le droit d'auteur. L’utilisation des services d'Érudit (y compris la reproduction) est assujettie à sa politique d'utilisation que vous pouvez consulter en ligne.

https://apropos.erudit.org/fr/usagers/politique-dutilisation/ 


\title{
Interfertility between Armillaria cepistipes and A. sinapina
}

\author{
Jean A. Bérubé ${ }^{1,2}$, Michel Dessureault ${ }^{1}$, Suzanne Berthelay ${ }^{3}$, \\ and Jean-Jacques Guillaumin ${ }^{3}$
}

Received 1996-01-26; accepted 1996-08-04

\begin{abstract}
European strains of Armillaria cepistipes were reported to be interfertile with strains from three American Armillaria species known as North American Biological Species (NABS) V (A. sinapina), NABS X and NABS XI. Such interfertility between species raises some doubts about using different Latin binomials for species capable of mating. This interfertility was reinvestigated by mating 24 haploid isolates of European $A$. cepistipes with 23 isolates of $A$. sinapina from North America and Asia. Individual pairings were independently performed at least once at Université Laval, Canada and at INRA ClermontFerrand, France. From the 420 interspecific pairings performed at Laval, two were positive and seven were ambiguous for a total of $2.1 \%$ of all the pairings. From the 506 pairings made at Clermont-Ferrand, 10 were positive and 24 were ambiguous for a total of $6.7 \%$. The differences in the pairing results may be explained by incubation temperatures, and the different types and concentrations of malt extract used at each laboratory. The low levels of interfertility found between $A$. cepistipes and $A$. sinapina may result from the absence of genetic barriers that are usually present between sympatric species. This low level of interfertility reflects differences in morphology, distribution, and habitat for these two species of Armillaria and this supports the retention of different species denominations.
\end{abstract}

Bérubé, J.A., M. Dessureault, S. Berthelay et J.-J. Guillaumin. 1996. Interfertilité entre Armillaria cepistipes et A. sinapina. PHYTOPROTECTION 77 : 67 74.

Des études ont rapporté que des lignées européennes d'Armillaria cepistipes étaient interfertiles avec trois lignées américaines d'Armillaria désignées par les termes espèce biologique nord-américaine (NABS) $\vee(A$. sinapina), NABS $X$ et NABS XI. Une telle interfertilité entre les espèces soulève des doutes au sujet de l'utilisation de binômes latins distincts pour des espèces pouvant se reproduire. Cette interfertilité a été ré-examinée en mettant 24 isolats haploïdes $\mathrm{d}^{\prime} A$. cepistipes européen en présence de 23 isolats d'A. sinapina d'Amérique du Nord et d'Asie. Les appariements individuels ont été effectués de façon indépendante au moins une fois à I'Université Laval (Canada) et à I'INRA

1. Centre de recherche en biologie forestière, Faculté de foresterie et de géomatique, Université Laval, Québec, Canada G1K 7P4

2. Current address: Service Canadien des Forêts, Région du Québec, 1055, rue du PEPS, C.P. 3800, Sainte-Foy (Québec), Canada G1V 4C7. Author to whom correspondence should be addressed

3. Institut National de la Recherche Agronomique, Centre de recherche de Clermont-FerrandTheix, Unité de Mycologie, 12, avenue du Brézet, 63039, Clermont-Ferrand, France 
Clermont-Ferrand (France). Des 420 appariements interspécifiques effectués à I'Université Laval, deux étaient positifs et sept étaient ambigus, pour un total de 2,1\% de tous les appariements. Des 506 appariements effectués à ClermontFerrand, 10 étaient positifs et 24 étaient ambigus pour un total de 6,7\% des appariements. Les différences dans les résultats de ces appariements peuvent être expliquées par les températures d'incubation, ainsi que par les différents types et concentrations d'extrait de malt utilisés dans chaque laboratoire. Les bas niveaux d'interfertilité trouvés entre $A$. cepistipes et $A$. sinapina peuvent résulter de l'absence de barrières génétiques habituellement présentes entre des espèces sympatriques. Ce bas niveau d'interfertilité reflète des différences entre la morphologie, la répartition et les habitats des deux espèces d'Armillaria, et appuie la conservation de dénominations d'espèces distinctes.

\section{INTRODUCTION}

Development of a crustose colony morphology after pairing two compatible haploid strains proved to be a useful and highly productive method to determine biological species and later to delineate taxa in the root-pathogenic genus Armillaria (Fr.) Staude (Anderson and Ullrich 1979; Kile and Watling 1988; Korhonen 1978). This technique has led to the recognition of at least nine biological species of Armillaria in North America and seven species in Europe. Most of these biological species of Armillaria have also been linked to morphological taxa and are now referred to by their Latin names (Bérubé and Dessureault 1988, 1989; Guillaumin et al. 1989). However, Anderson et al. (1980) reported cases of interfertility between isolates of a species from Europe with members of two other rigorously intersterile species from North America. In particular, they reported positive or ambiguous pairings in 4 out of 30 pairings between European Armillaria species $\mathrm{B}$ (now named $A$. cepistipes Velenovsky), with isolates of North American Biological Species (NABS) V, (now named $A$. sinapina Bérubé \& Dessureault), which commonly occurs in the deciduous forests of the province of Quebec. In addition, European $A$. cepistipes was also reported to have a high percentage of interfertily with NABS XI (Morrison et al. 1985) which occurs in western Canada. This interfertility brings into question the legitimacy of using two different specific epithets for groups showing partial interfertility. This study was conducted to pair a larger number of isolates from both $A$. cepistipes and A. sinapina, allowing the examination and quantification of interfertility.

\section{MATERIAL AND METHODS}

Strains used for pairings consisted of 23 monosporous isolates previously labeled as $A$. sinapina and 24 monosporous isolates previously labeled as $A$. cepistipes from Europe, North America, and Asia. The strains and origins are listed in Table 1. The pairings were performed independently at Université Laval in Québec (lat. $46^{\circ} 48^{\prime} \mathrm{N}$, long. $71^{\circ} 23^{\prime} 0$ ), Canada and at INRA in Clermont-Ferrand (lat. $45^{\circ} 45^{\prime} \mathrm{N}$, long. $03^{\circ} 06^{\prime} 0$ ), France. At Université Laval, 863 pairings (420) interspecific, 443 intraspecific) were performed by confronting 21 strains of $A$. sinapina and 20 strains of $A$. cepistipes in all possible combinations of within and between species. The 506 pairings performed at Clermont-Ferrand were done with 23 strains of $A$. sinapina and 24 strains of $A$. cepistipes in all possible combinations between species. Individual pairings were performed in petri dishes in such a way that the paired mycelia contacted each other (Korhonen and Hintikka 1980). Pairings were grown for at least 21 days in the dark at $20^{\circ} \mathrm{C}$ at Université Laval and $23-24^{\circ} \mathrm{C}$ at ClermontFerrand. Preparation of growth media differed between the two institutions. At Université Laval, purified malt extract (Difco) at a concentration of $1.25 \%$ was used while unpurified baker's malt (Difal) at a concentration of $2 \%$ was used at Clermont-Ferrand. The positive or ambiguous pairings were replated twice to confirm results. The combined results of both teams of researchers are reported. 
Table 1. Name and origin of $A$. cepistipes and $A$. sinapina strains used in matings

\begin{tabular}{|c|c|}
\hline Name & Origin \\
\hline \multicolumn{2}{|l|}{ A. cepistipes } \\
\hline 67.1 .1 & St-Victor, Puy-de-Dôme, France \\
\hline 79.16 .3 & Col de la Moreno, Puy-de-Dôme, France \\
\hline 80.38 .5 & Puy de la Moreno, Puy-de-Dôme, France \\
\hline 80.16 .2 & Puy de Lachamps, Puy-de-Dôme, France \\
\hline 82.56 .4 & Trentin, Italy \\
\hline 84.89 .3 & Schwarzwald, Unterbrand, Germany \\
\hline 84.90 .1 & Vosges, France \\
\hline 84.91 .3 & Loffingen, Schwarzwald, Germany \\
\hline 84.93.3 & Lizzano, Italy \\
\hline 87.87 .1 & Moscow, Russia \\
\hline 87.87 .2 & Moscow, Russia \\
\hline $8509191 / 5$ & Lammertal, Austria \\
\hline $88090141 / 3$ & Tuusula, Finland \\
\hline $88090211 / 6$ & Tuusula, Finland \\
\hline $523 \mathrm{M} 4$ & Fall, Bayern, Germany \\
\hline $597 \mathrm{M} 3$ & Blomberg, Bayern, Germany \\
\hline B8 & Bad Tota, Bayern, Germany \\
\hline B9 & Fussen, Bayern, Germany \\
\hline 79.23 & Tampere, Finland \\
\hline 79.24 & Helsinki, Finland \\
\hline 84.93.1 & Lizzano, Italy \\
\hline 81.23.1 & Forêt de Tronçais, Allier, France \\
\hline 84.92 .2 & Vosges, France \\
\hline $472 \mathrm{M} 3$ & Waalberg, Bayern, Germany \\
\hline \multicolumn{2}{|l|}{ A. sinapina } \\
\hline JB-05B & Bromont, Québec, Canada \\
\hline JB-07A & Bromont, Québec, Canada \\
\hline JB-19E & Lac St-Jean, Québec, Canada \\
\hline JB-43A & Beauce, Québec, Canada \\
\hline JB-47A & Beauce, Québec, Canada \\
\hline JB-66A & Beauce, Québec, Canada \\
\hline JB-72A & Beauce, Québec, Canada \\
\hline JB-75B & Beauce, Québec, Canada \\
\hline MOR-84-14 & British Columbia, Canada \\
\hline MOR-84-1 & British Columbia, Canada \\
\hline $48-1$ & New York, USA \\
\hline $48-5$ & New York, USA \\
\hline 83.62 .1 & New York, USA \\
\hline 83.91 .1 & Petersburg, Alaska, USA \\
\hline 83.92 .1 & Petersburg, Alaska, USA \\
\hline 83.61 .1 & Vermont, USA \\
\hline 84.51 .1 & Vernon, British Columbia, Canada \\
\hline 84.51 .2 & Vernon, British Columbia, Canada \\
\hline 86.36 .3 & Dailing, China \\
\hline 86.37 .2 & Dailing, China \\
\hline JB-47B & Beauce, Québec, Canada \\
\hline 86.6 .1 & Hokkaido, Japan \\
\hline 86.7.1 & Hokkaido, Japan \\
\hline
\end{tabular}




\section{RESULTS}

Fertility within biological species was quantified by making 210 pairings for both A. sinapina and A. cepistipes. The results of the intraspecific crosses are shown in Tables 2 and 3.

Intraspecific pairings for $A$. sinapina yielded an overall fertility of $83.8 \%$. Fertility varied from one isolate to another. When paired with all other isolates, strain 86.7.1 gave negative results and was diagnosed as not to belong to $A$. sinapina (Table 2). Strain 86.7.1 was kept for interspecific pairings but was not scored in the final results. Strains JB-47A and 83.92.1 showed the lowest level of fertility with $60 \%$ and $65 \%$, respectively. Other strains like JB-19E and 83.91.1 were fertile with all other strains.

Intraspecific pairings of $A$. cepistipes yielded an overall fertility of $81.4 \%$ (Table 3). Five pairings were ambiguous. Fertility varied from one isolate to another. Strain $472 \mathrm{M} 3$ gave negative results with all pairings and was diagnosed as not to belong to A. cepistipes. It was kept for interspecific pairings but was not scored in the final results. Strain 87.87.1 exhibited very low fertility $(11 \%)$ with other strains of $A$. cepistipes. Isolate 87.87.2 was from the same fruit body (data not shown) and exhibited normal fertility levels, which lead us to believe strain 87.87 .1 to be defective, which sometimes happens when monosporous strains age. Although 87.87.1 was defective, it was scored in the final results. The next lowest level of fertility was $63 \%$ with strain 79.24. Other strains like 84.89 .3 and 84.90 .1 were fertile with all others tested, except for strain 87.87.1 as expected.

Interspecific crosses between isolates of $A$. sinapina and $A$. cepistipes yielded low levels of interfertility (Table 4). Significant differences were observed between results from Université Laval and Clermont-Ferrand. Positive and ambiguous pairings totaled $2.1 \%$ at Université Laval while reaching $6.7 \%$ at ClermontFerrand. However, the most important difference came from the positive pairings which did not include the same strain combinations except for two cases. Pairings MOR-84-1 X 84.89.3 and
79.24 X MOR-84-1 were both evaluated as positive or somewhat positive by both research groups. All other pairings were scored as negative by one research group.

Interfertility was not uniform among strains. For example, A. cepistipes strains 67.1.1, 88090141/3, 84.89.3, and 79.23, exhibited $41 \%, 32 \%, 23 \%$, and $18 \%$ interfertility, respectively, with $A$. sinapina isolates. The majority of the pairings showed little or no interfertility. Similarly, A. sinapina strains MOR-84-1 and JB$07 \mathrm{~A}$ exhibited $26 \%$ and $22 \%$ interfertility, respectively. No genetic interactions between isolates from different regions are evident from Table 4.

\section{DISCUSSION}

The differences in the results of interspecific pairings between the two research groups were unexpected. Although similar low levels of interfertility were observed, the combinations of positive pairings were different from one research group to the other. Since interpretation of positive pairings are usually standard, false interpretation was ruled out as the cause of discrepancy on positive pairings. These discrepancies may be due to the incubation temperatures, and the type and concentration of malt extract used. The media used at Université Laval probably offered minimal growth conditions and may have had an adverse effect on matings. The media used at ClermontFerrand was richer, more concentrated, and may have been more favorable for growth. Matings may have had full potential to occur and as well as continued growth afterward under these conditions. Alternative methods should be used, such as presence of clamp connections (Larsen et al. 1992) or nuclear migration demonstrated by isoenzyme markers on each strain to screen ambiguous pairings (Rizzo and Harrington 1992).

The low level of interfertility between $A$. sinapina and $A$. cepistipes combined with the high level of fertility within each species supports the use of two distinct Latin names for these species and also reflect differences in morphology, distribution, and habitat. Such low levels of interfertility between species could be explained by the absence of genetic bar- 
Table 2. Intraspecific pairings of isolates of $A$. sinapina

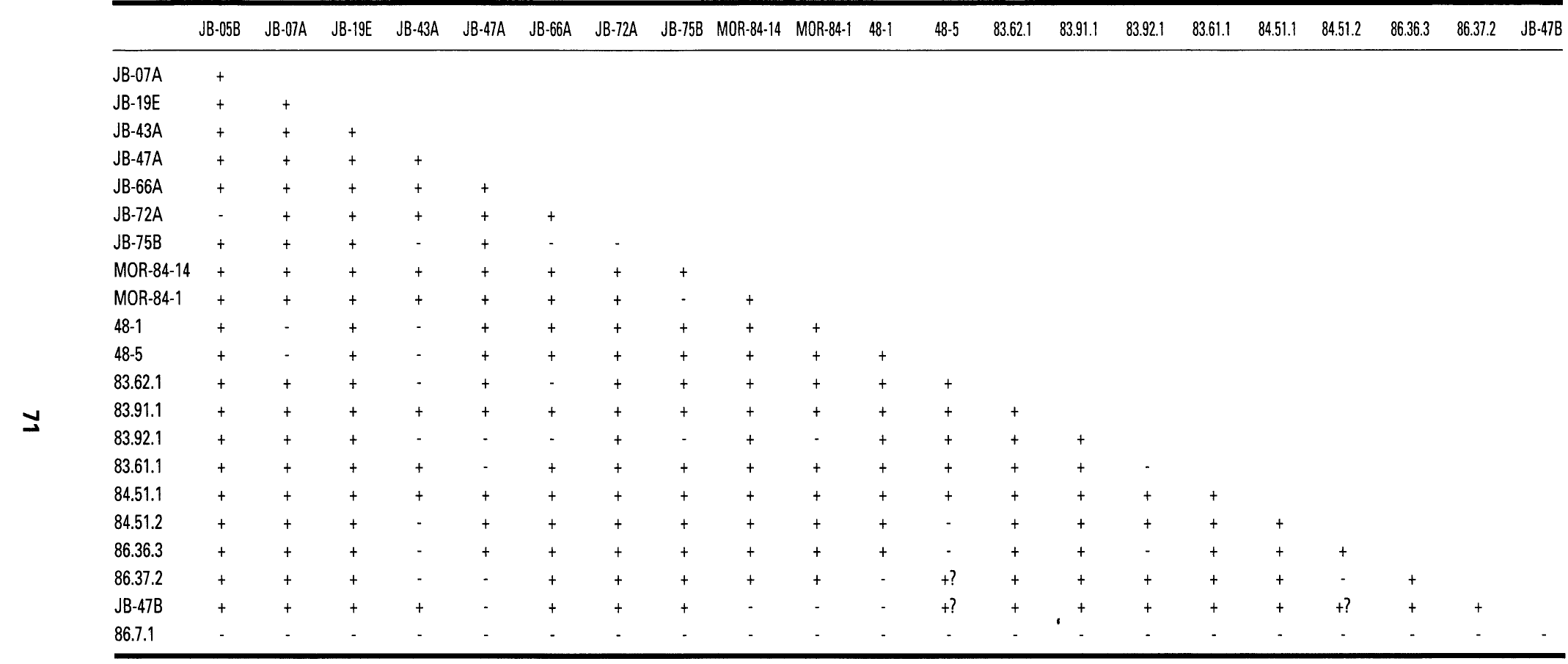

Positive interactions $(+)$, questionable interactions $(+?)$ and negative interactions $(-)$. 
PHYTOPROTECTION 77 (2) 1996

Table 3. Intraspecific pairings of isolates of $\boldsymbol{A}$. cepistipes

\begin{tabular}{|c|c|c|c|c|c|c|c|c|c|c|c|c|c|c|c|c|c|c|c|c|}
\hline & 67.1 .1 & 79.16 .3 & 80.38 .5 & 80.16 .2 & 82.56 .4 & 84.89 .3 & 84.90 .1 & 84.91 .3 & 84.93 .3 & 87.87 .1 & $8509191 / 5$ & $88090141 / 3$ & $88090211 / 6$ & $523 M 4$ & $472 \mathrm{M} 3$ & $597 \mathrm{M} 3$ & B8 & B9 & 79.23 & 79.24 \\
\hline 79.16 .3 & + & & & & & & & & & & & & & & & & & & & \\
\hline 80.38 .5 & $+?$ & + & & & & & & & & & & & & & & & & & & \\
\hline 80.16 .2 & - & $?$ & + & & & & & & & & & & & & & & & & & \\
\hline 82.56 .4 & + & + & + & + & & & & & & & & & & & & & & & & \\
\hline 84.89 .3 & + & + & + & + & + & & & & & & & & & & & & & & & \\
\hline 84.90 .1 & + & + & + & + & + & + & & & & & & & & & & & & & & \\
\hline 84.91 .3 & + & + & + & + & + & + & $+?$ & & & & & & & & & & & & & \\
\hline 84.93 .3 & + & + & . & + & + & + & + ? & + & & & & & & & & & & & & \\
\hline 87.87 .1 & - & - & - & - & - & - & - & - & - & & & & & & & & & & & \\
\hline $8509191 / 5$ & + & + & + & + & + & + & + & + & + & - & & & & & & & & & & \\
\hline $8890141 / 3$ & $+?$ & $+?$ & $+?$ & $+?$ & + ? & + & + & $+?$ & - & - & + ? & & & & & & & & & \\
\hline $8890211 / 6$ & + & + & + & + & + & + & + & + & + & + & + & + & & & & & & & & \\
\hline $523 \mathrm{M} 4$ & + & + & + & + & + & + & + & + & + & - & + & + & + & & & & & & & \\
\hline $472 \mathrm{M} 3$ & - & - & - & - & - & - & - & - & - & - & - & - & - & - & & & & & & \\
\hline $597 \mathrm{M} 3$ & + & + & + & + & + & + & + & + & $+?$ & $+?$ & - & + & + & + & - & & & & & \\
\hline B8 & + & + & + & + & + & + & . & $?$ & + & - & + & - & - & $+?$ & . & + & & & & \\
\hline B9 & + & + & + & + & + & + & + & + & + & - & + & + & + & + & - & + & + & & & \\
\hline 79.23 & + & + & + & + & + & + & + & + & + & $?$ & + & + & + & + & - & $?$ & + & + & & \\
\hline 79.24 & + & + & + & + & + & + & + & + & $?$ & - & + & - & - & + & - & + & - & - & + & \\
\hline 84.93 .1 & + & + & + & + & + & + & $+?$ & $+?$ & - & - & + & $+?$ & + & + & - & + & - & + & + & - \\
\hline
\end{tabular}

Positive interactions $(+)$, questionable interactions $(+?, ?)$ and negative interactions $(-)$. 
Table 4. Interspecific pairings of isolates of $\boldsymbol{A}$. sinapina and $\boldsymbol{A}$. cepistipes

\begin{tabular}{|c|c|c|c|c|c|c|c|c|c|c|c|c|c|c|c|c|c|c|c|c|c|c|c|}
\hline & JB-05B & $J B-07 A$ & JB-19E & $J B-43 A$ & $J B-47 A$ & $J \mathrm{~B}-66 \mathrm{~A}$ & $J B-72 A$ & JB- $75 B$ & MOR-84-14 & $48-1$ & MOR-84-1 & $48-5$ & 83.62 .1 & 83.91 .1 & 83.92 .1 & 83.61 .1 & 84.51 .1 & 84.51 .2 & 86.36 .3 & 86.37 .2 & $J B-47 B$ & 86.6 .1 & 86.7 .1 \\
\hline 67.1 .1 & ? & $-?$ & - & - & - & $-?$ & $-?$ & -+ & + & - & -+ & - & - & - & - & + & - & $-?$ & - & - & - & . & - \\
\hline 79.16 .3 & - & - & - & - & - & $-?$ & - & - & - & - & $?-$ & - & - & - & - & - & - & - & - & - & . & - & - \\
\hline 80.38 .5 & - & +- & - & - & - & - & - & - & - & - & - & - & - & - & - & - & - & - & - & - & - & - & - \\
\hline 80.16 .2 & - & - & - & - & - & - & - & - & - & - & - & - & - & - & - & - & - & - & - & - & - & - & - \\
\hline 82.56 .4 & . & - & - & - & - & - & - & - & - & - & - & $+?-$ & - & - & - & - & - & - & - & - & - & - & - \\
\hline 84.89 .3 & - & - & - & - & - & - & - & - & - & - & $+?+$ & - & - & -+ & $-?$ & + & $+?-$ & - & - & - & - & - & - \\
\hline 84.90 .1 & - & - & - & - & - & - & - & - & - & - & - & - & - & - & $-?$ & - & - & - & - & - & - & - & - \\
\hline 84.91 .3 & - & - & - & - & - & - & - & - & - & - & - & - & - & - & - & - & - & - & - & - & - & - & - \\
\hline 84.93 .3 & - & - & - & - & - & $-?$ & - & - & - & - & - & - & - & - & - & - & - & - & - & - & - & - & - \\
\hline 87.87 .1 & - & - & - & - & - & - & - & - & - & - & - & - & - & - & - & - & - & - & - & - & - & - & - \\
\hline $8509191 / 5$ & - & - & - & - & - & - & - & - & - & - & - & - & - & - & - & - & - & - & - & - & - & - & - \\
\hline $8890141 / 3$ & $?$ & $-?$ & - & - & - & - & - & - & - & - & $-?$ & - & - & - & - & -+ & $-?$ & $-?$ & $-?$ & - & - & - & - \\
\hline $8890211 / 6$ & - & - & - & - & - & - & - & - & - & - & - & - & - & - & - & - & - & - & - & - & - & - & - \\
\hline $523 \mathrm{M} 4$ & - & $+?-$ & - & - & - & - & - & - & - & - & - & - & - & - & - & - & - & - & $-?$ & - & - & - & - \\
\hline 87.87 .2 & - & - & - & - & - & - & - & - & - & - & - & - & - & - & - & - & - & - & - & - & - & - & - \\
\hline $597 \mathrm{M} 3$ & - & - & - & - & - & - & - & - & - & - & - & - & - & - & - & - & - & - & - & - & - & - & - \\
\hline B8 & . & - & - & - & - & - & - & - & - & $-?$ & + & + & - & - & - & - & - & - & - & - & - & - & - \\
\hline B9 & - & - & - & - & - & - & - & - & - & - & - & - & - & - & - & - & - & - & - & - & - & - & - \\
\hline 79.23 & - & $-?$ & $-?$ & - & - & - & - & - & - & - & - & - & - & $-?$ & $-?$ & - & - & - & - & . & - & - & - \\
\hline 79.24 & - & - & - & - & - & - & - & - & - & - & $++?$ & - & - & - & - & - & - & - & - & - & - & + & - \\
\hline 84.93 .1 & - & - & - & - & - & - & - & - & - & - & - & - & - & $-?$ & - & - & - & - & $-?$ & - & - & - & - \\
\hline 81.23 .1 & - & - & - & - & - & - & - & - & - & - & - & - & - & - & - & - & - & $-?$ & - & - & - & - & - \\
\hline 84.92 .2 & - & - & - & - & - & - & - & - & - & - & - & - & - & - & - & - & - & - & - & - & - & - & - \\
\hline $472 \mathrm{M} 3$ & - & - & - & - & - & - & - & - & - & - & - & - & - & - & - & - & - & - & - & - & - & - & - \\
\hline
\end{tabular}


riers that are usually present in sympatric species. It is interesting to note that A. sinapina which was initially thought to be found only in North America has been found in Asia (i.e. Japan and Manchuria). Similarly, A. cepistipes thought to be found only in Europe has been shown to be interfertile with NABS XI from British Columbia (Morrison et al. 1985). Thus $A$. sinapina and $A$. cepistipes are considered sympatric in British Columbia. Crosses to evaluate levels of interfertility of British Columbian strains from both species would address this issue.

The low levels of interfertility between two species, such as the one reported in this study, could be useful to understand the genetic system that regulates interfertility or mating systems. A study such as that used by Chase and Ullrich (1990) on Heterobasidion annosum (Fr.) Bref. may be done with these two species of Armillaria. However, for such a study, the use of colony morphology alone as a criteria for mating could be problematic as demonstrated by our results. Positive or ambiguous matings could be checked using nuclear migration as demonstrated by isoenzyme or DNA analysis.

\section{ACKNOWLEDGMENTS}

The authors would like to thank the following people for supplying strains and making this study possible: D. Lamoure, H. Marxmuller, K. Korhonen, J.B. Anderson, C. Shaw, D. Morrison, J. Rishbeth, and $\mathrm{T}$. Terashita.

\section{REFERENCES}

Anderson, J.B., and R.C. Ullrich. 1979. Biological species of Armillaria mellea in North America. Mycologia 71 : 402-414.

Anderson, J.B., K. Korhonen, and R. Ullrich. 1980. Relationships between European and North American Biological species of Armillaria mellea. Exp. Mycol. 4: 87-95.
Bérubé, J.A., and M. Dessureault. 1988. Morphological characterization of Armillaria ostoyae and Armillaria sinapina sp. nov. Can. J. Bot. 66 : 2027-2034.

Bérubé, J.A., and M. Dessureault. 1989. Morphological studies of the Armillaria mellea complex: Two new species, $A$. gemina and A. calvescens. Mycologia 81 : 216-225.

Chase, T.E., and R.C. Ullrich. 1990. Five genes determining intersterility in Heterobasidion annosum. Mycologia 82 : 73-81.

Guillaumin J.-J., C. Mohammed, and S. Berthelay. 1989. Armillaria species in the northern temperate hemisphere. Pages 27-43 in D.J. Morrison (ed), Proceedings of the $7^{\text {th }}$ IUFRO Int. Conf. Root and Butt Rots of Forest Trees. Pacific Forest Centre, Victoria, B.C., Canada.

Kile, G.A., and R. Watling. 1988 . Identification and occurrence of Australian Armillaria species, including $A$. pallidula sp. nov. and comparative studies between them and non Australian tropical and Indian Armillaria. Trans. Br. Mycol. Soc. 90 : 872882.

Korhonen, K. 1978. Interfertility and clonal size in the Armillaria mellea complex. Karstenia 18: 31-42.

Korhonen, K., and V. Hintikka. 1980. Simple isolation and inoculation methods for fungal cultures. Karstenia $20: 19-22$.

Larsen, M.J., M.T. Banik, and H.H. Burdsall. 1992. Clamp connections in North American Armillaria species : occurrence and potential application for delimiting species. Mycologia 84 : 214-218.

Morrison, D.J., D. Chu, and A.L.S. Johnson. 1985. Species of Armillaria in British Columbia. Can. J. Plant Pathol. 7 : 242-246.

Rizzo, D.M., and T.C. Harrington. 1992. Nuclear migration in diploid-haploid pairings of Armillaria ostoyae. Mycologia 84 : 863869. 